\author{
R.V. Korol ${ }^{1}$, O.M. Yanchuk ${ }^{2}$, O.V. Marchuk ${ }^{2}$, V.F. Orlov³ ${ }^{3}$ I.A. Moroz ${ }^{4}$, O.A. Vyshnevskyi ${ }^{5}$
}

\title{
Size Stabilizers in Two-electrode Synthesis of ZnO Nanorods
}

\author{
${ }^{1}$ California Institute of Technology, Pasadena, USA, rkorol@caltech.edu \\ ${ }^{2}$ Lesya UkrainkaVolyn National University, Lutsk, Ukraine, yanchuk59@gmail.com \\ ${ }^{3}$ Institute of Vocational Education and Training of the NAPS of Ukraine, Kyiv, Ukraine, v.f.orlov@ukr.net \\ ${ }^{4}$ Lutsk National Technical University, Lutsk,Ukraine, moroz.irynal@gmail.com \\ ${ }^{5}$ M.P.Semenenko Institute of Geochemistry, Mineralogy and Ore Formation NAS of Ukraine, Kyiv, Ukraine, vyshnevskyy@i.ua
}

\begin{abstract}
We modify and optimize a cheap, simple and effective synthesis of zinc oxide nanosized particles by electrodeposition. The core method encompasses the synthesis of $\mathrm{ZnO}$ product on the soluble zinc anode of the two-zinc-electrode cell emerged in aqueous $\mathrm{NaCl}$. Resulting particles have the plate shape, wider in the middle and sharp at the edges. They have uniform shape, but broad size distributions with most of the ZnO product $1-2 \mu \mathrm{m}$ long and $0.5-0.7 \mu \mathrm{m}$ wide. Thus, auxiliary stabilizers are added to aqueous phase to reduce the size and narrow its distribution in the target product. Here we present the size stabilizing action of four successful stabilizers: urea, polyvinyl alcohol, Triton X-100 and Atlas G3300. All of them reduce particle size and polydispersity. An anionactive surfactant Atlas G3300 is the most effective, giving an order of magnitude nanorod size reduction.
\end{abstract}

Keywords: $\mathrm{ZnO}$, nanorods, electrodeposition, oxidation, surfactants.

Received 3June2021; Accepted 14June2021.

\section{Introduction}

1D semiconductor nanostructures (nanorods and nanowires) already play an important role as both interconnects and functional units in the fabrication of electronic, optoelectronic, electrochemical, and electromechanical nanodevices [1]. It is also argued that their unique properties make them great building blocks for the new generations of electronic and photonic devices [2].

$\mathrm{ZnO}$ is a semiconductor material with a direct wide band gap energy $(3.37 \mathrm{eV})$ and a large exciton binding energy $(60 \mathrm{meV})$ at room temperature [3]. It crystallizes in two main forms, hexagonal wurtzite, and cubic zinc blende. A comprehensive review of properties, preparation, processing, and device applications of $\mathrm{ZnO}$ is presented elsewhere [4]. Here we only briefly motivate the development of synthetic methods aiming at $\mathrm{ZnO}$ wurtzite nanorods by noting their significance.

$\mathrm{ZnO}$ nanoparticles are attractive candidates for various technological applications such as UV lasers [5], light-emitting diodes [6], solar cells [7] and stills [8], nanogenerators [9], gas sensors [10,11], UV photodetectors [12], and photocatalysts [13-16]. $\mathrm{ZnO}$ is also biocompatible and biodegradable[17], and therefore suitable for medical [18] and environmental applications [19]. Most interestingly, the properties of zinc oxide as a material strongly depend on the dimensionality, size and morphology of the $\mathrm{ZnO}$ nanostructures [13,20-22].

Nowadays there is a multitude of synthetic methods to obtain ZnO. To name a few, vapor-phase transport [23], sol electrophoretic deposition [24], hydrothermal/solvothermal growth [3,16,25], arc discharge [26], chemical bath deposition [12,27,28], or electrochemical deposition [29-31] (both anodic [32-34] and cathodic $[35,36])$. They differ in their approach, cost, and ultimate results. The two-electrode neural aqueous synthesis is simple, green and cheap, gives high yields and allows the current-time control of product quantity $[20,30,32,34,37-39]$. It is successfully used for the manufacture of $\mathrm{ZnO}$ thin films [40]. It is also suitable for electrochemical synthesis of $1 \mathrm{D} \quad \mathrm{ZnO}$ 


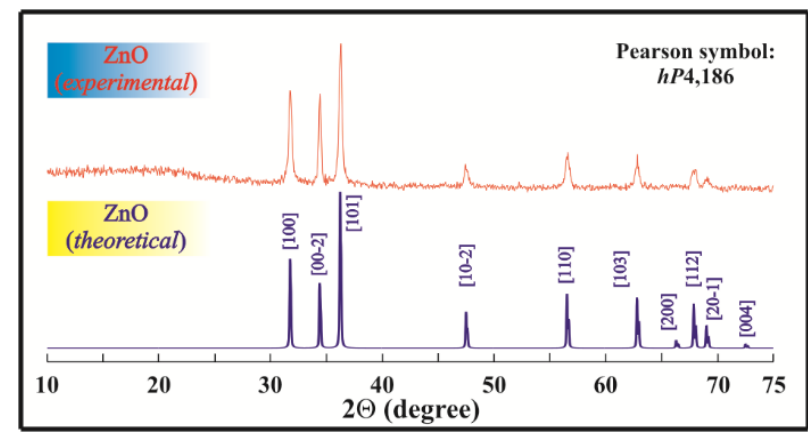

(a)

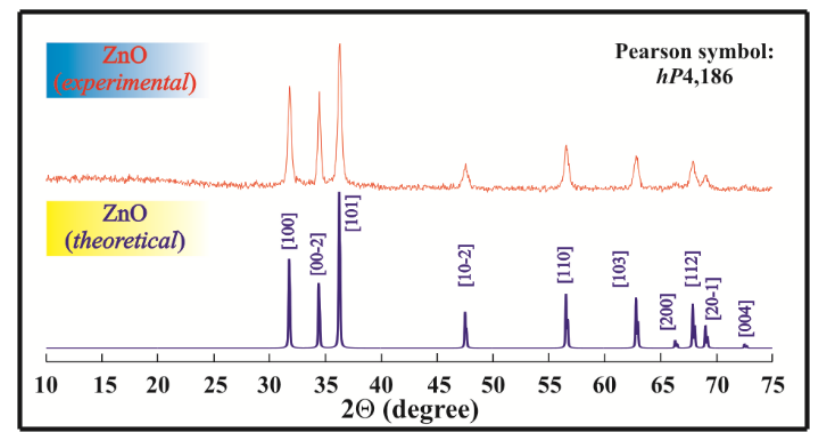

(b)

Fig. 1.XRD spectra of the $\mathrm{ZnO}$ products (experimentalin red) (a) without stabilizers and (b) synthesized with Atlas G3300. These are super imposed on the theoretical $P 6_{3} m c$ wurtzite $\mathrm{ZnO}$ peaks (shown in blue).

Table 1

Conditions of Synthesis and corresponding yields

\begin{tabular}{|c|c|c|c|c|c|}
\hline $\begin{array}{l}\text { Current density } \\
\mathrm{mA} / \mathrm{cm}^{2}\end{array}$ & 25 & 50 & 75 & 100 & 125 \\
\hline control & $1 \mathrm{~A}(93 \%)$ & 1B $(91 \%)$ & $1 \mathrm{C}(92 \%)$ & $1 \mathrm{D}(92 \%), 1 \mathrm{D} *(91 \%), 1 \mathrm{D}+(90 \%)$ & $1 \mathrm{E}(93 \%)$ \\
\hline urea & $2 \mathrm{~A}(94 \%)$ & 2B $(91 \%)$ & $2 \mathrm{C}(90 \%)$ & $2 \mathrm{D}(95 \%), 2 \mathrm{D}+(90 \%)$ & $2 \mathrm{E}(93 \%)$ \\
\hline PVA & $3 \mathrm{~A}(94 \%)$ & 3B (93\%) & $3 \mathrm{C}(95 \%)$ & 3D (94\%), 3D+ (93\%) & $3 \mathrm{E}(95 \%)$ \\
\hline Triton $X-100$ & 4A (93\%) & 4B (91\%) & $4 \mathrm{C}(90 \%)$ & $4 \mathrm{D}(94 \%)$ & $4 \mathrm{E}(93 \%)$ \\
\hline Atlas G3300 & $5 \mathrm{~A}(93 \%)$ & 5B (94\%) & $5 \mathrm{C}(91 \%)$ & $5 \mathrm{D}(93 \%), 5 \mathrm{D} *(92 \%), 5 \mathrm{D}+(94 \%)$ & $5 \mathrm{E}(94 \%)$ \\
\hline
\end{tabular}

Unmarked syntheses are 5 minutes long, * signifies 10-minute and + marks a 15-minute synthesis.

nanostructures [20,32,37,38]. Current density [29] and electrolysis time [41] have been shown to impact $\mathrm{ZnO}$ microstructures in other electrodeposition methods. Earlier we also [38] examined how electrolysis time and current density affects the product's topology in our set-up and as a result changes its photo-induced piezoelectric properties.

This article reports further method development: we are testing four candidates for the size stabilizing precursors in a range of synthetic conditions. Hydrothermal syntheses of $\mathrm{ZnO}$ with the use of solvents [8], polymers [42-44], salicylic acid [45], amino acids [46] and surfactants [3] were reported earlier. Our current choice of stabilizers tested is not random. The compounds that we are testing were used earlier in different synthetical procedures aiming at $\mathrm{ZnO}$ : urea [47] as an alkali source together with $\mathrm{N}_{2} \mathrm{H}_{4}$ and as a stabilizer [48], PVA [49-51]. Surfactants that are tested represent two different groups: non-ionic Triton X-100 and anionic Atlas G3300 (formulas and chemical names can be found in Figure 5). To the best of our knowledge only polymetacrylic acid and cationic surfactant CTAB [52] were tested as stabilizers in an analogous synthetic procedure earlier.

$\mathrm{ZnO}$ synthesis by anodization is studied only fragmentarily and the mechanism is not completely understood [32]. There are many other factors affecting the $\mathrm{ZnO}$ product: temperature [53], electrolyte type and concentration [30,32,53] and even the orientation of electrodes [32]. Optimization of synthetic conditions is therefore promising, but extremely challenging with a multitude of factors to control.

\section{Main Text}

In the electrolytic cell

$$
Z n_{(s)}\left|0.856 M \operatorname{NaCl}_{(a q)}\right| Z n_{(s)}
$$

the following half-reactions occur on the electrodes:

$$
\begin{gathered}
(A,+) Z n=Z^{2+}+2 e^{-} \\
(C,-) H_{2} O+2 e^{-}=O^{2-}+H_{2}
\end{gathered}
$$

The total equation for electrolysis then reads:

$$
\mathrm{Zn}+\mathrm{H}_{2} \mathrm{O}=\mathrm{ZnO}+\mathrm{H}_{2}
$$

\subsection{Characterization of the $\mathrm{ZnO}$ product}

Dried particles are analyzed using XRD and the experimental peaks are in perfect agreement with $P 6 \_3 m c$ wurtzite phase $\mathrm{ZnO}$ (Fig. 1). These results are consistent with earlier reports of zinc oxide synthesis via electrodeposition at high temperatures in aqueous neutral electrolyte [20,37,38]. The XRD spectra of unstabilized particles (panel a) and those made in the presence of each of the four stabilizers (product of the synthesis with Atlas G3300 is given on panel $b$ as an example) are essentially identical (XRD spectra of with other). Therefore, the presence of stabilizers affects neither chemical composition nor crystalline phase of synthesized particles. Nonetheless, peaks on panel (b) are significantly broader compared to panel (a), indicating the smaller particle size of the latter.

Percentage yields are calculated based on the decrease of the mass of the anode and presented in the Table 1. These are pleasantly but not unusually high 
Table 2

Average geometric sizes of the particles synthesized at different current densities with the stabilizers tested

\begin{tabular}{|l|c|c|c|c|c|}
\hline \multicolumn{1}{|c|}{ Conditions } & A & B & C & D & E \\
\hline 1, control & $944 \pm 264^{\mathrm{a}}$ & $1459 \pm 438$ & $1449 \pm 503$ & $1804 \pm 769$ & $1713 \pm 719$ \\
& $320 \pm 64^{\mathrm{b}}$ & $448 \pm 103$ & $443 \pm 169$ & $518 \pm 164$ & $501 \pm 155$ \\
\hline 2, urea & $862 \pm 288$ & $691 \pm 309$ & $828 \pm 392$ & $560 \pm 270$ & $942 \pm 270$ \\
& $230 \pm 68$ & $201 \pm 83$ & $260 \pm 101$ & $214 \pm 66$ & $259 \pm 76$ \\
\hline 3, PVA & $496 \pm 196$ & $1162 \pm 457$ & $860 \pm 240$ & $870 \pm 351$ & $927 \pm 384$ \\
& $210 \pm 81$ & $337 \pm 99$ & $360 \pm 113$ & $298 \pm 107$ & $315 \pm 96$ \\
\hline 4, triton x-100 & $729 \pm 292$ & $1082 \pm 335$ & $1170 \pm 461$ & $1129 \pm 393$ & $1126 \pm 307$ \\
& $259 \pm 63$ & $312 \pm 84$ & $336 \pm 111$ & $357 \pm 148$ & $344 \pm 75$ \\
\hline 5, atlas & $238 \pm 125$ & $177 \pm 40$ & $119 \pm 45$ & $109 \pm 45$ & $188 \pm 46$ \\
& $79 \pm 50$ & $51 \pm 28$ & $35 \pm 10$ & $34 \pm 9$ & $62 \pm 32$ \\
\hline
\end{tabular}

${ }^{a}$ mean particle lengths; ${ }^{b}$ mean width measured at the center of each particle.

Both are reported with the standard deviation, in the form $\mu \pm \sigma \mathrm{nm}$.

Table 3

Average geometric sizes of the particles synthesized at different electrolysis times with the stabilizers tested

\begin{tabular}{|l|c|c|c|}
\hline \multicolumn{1}{|c|}{ Conditions } & $\mathrm{D}$ & $\mathrm{D}$ & $\mathrm{D}+$ \\
\hline 1, control & $1804 \pm 769$ & $1068 \pm 468$ & $900 \pm 392$ \\
& $518 \pm 164$ & $369 \pm 119$ & $266 \pm 107$ \\
\hline 2, urea & $559 \pm 270$ & - & $892 \pm 355$ \\
& $214 \pm 66$ & - & $287 \pm 132$ \\
\hline 3, PVA & $870 \pm 351$ & - & $700 \pm 305$ \\
& $298 \pm 107$ & - & $122 \pm 110$ \\
\hline 5, atlas & $109 \pm 45$ & $110 \pm 46$ & $104 \pm 50$ \\
& $34 \pm 9$ & $34 \pm 9$ & $35 \pm 16$ \\
\hline
\end{tabular}

(compared to electrodeposition of other metal oxides and salts).

There are 5 series of experiments conducted, one with no stabilizer added (control) and four more (with each of 4 stabilizers). The total of 31 sets of conditions were tested to examine the influence of the stabilizers, current density (Table 2) and electrolysis time (Table 3) on the size and morphology of the $\mathrm{ZnO}$ product.

The unstabilized $\mathrm{ZnO}$ particles (syntheses $1 \mathrm{~A}$ to $1 \mathrm{E}$ ) have the plate shape, wider in the middle and sharp at the edges (figure 2). The size distribution is wide (row 1 of tables 2 and 3) with most of the synthesized particles being more than $1 \mu \mathrm{m}$ in length, but there is also a significant number of smaller particles (see figure 2).

The average particle size increases with higher current density (row 1 of table 2). This increase in average particle size is due to the reduced fraction of smaller particles at higher current densities (compare panels (a)-(c) of Figure 2 ). The positive correlation between current density and particle size can be explained by the faster product formation, leading to more aggregation due to a higher density of $\mathrm{ZnO}$ clusters.

Increasing the electrolysis time leads to smaller particles in the unstabilized syntheses (table 3, row 1 and panels (c),(d) in Figure 2.

\subsection{Effect of stabilizers}

The first thing to note in Tables 2 and 3 is that all four of the stabilizers tested result in a decrease of the average particle sizes for all the conditions tested. One might expect that the stabilizers will be less effective when the rate of the synthesis is higher (at higher current densities). However, they remain effective over the full range of current densities tested. PVA and Triton X-100 predictably give smallest particles at lowest current density (mirroring the trend observed in the case without the stabilizer). Urea and Atlas G3300, on the other hand, seem to have an optimal current density of around $100 \mathrm{~mA} / \mathrm{cm}^{2}$.

In the control syntheses increasing electrolysis time led to the decrease of the average particle size (table 3 and Figure 2). So another important question one might ask is whether the stabilizers are as effective for longer syntheses. If the stabilization is kinetic, it can be undermined over time by aggregation, and/or reaching the equilibrium size.

This is indeed what is happening with urea. When the electrolysis is 5 minutes long, there is a considerable size reduction (see Table 3 and compare Figures 2(c) and 5(a)). However, the 15-minute syntheses are unaffected by the presence of urea (column D+ of table 3, compare Figures 2(d) and 5(b)).

On the other hand, PVA decreases the average size 


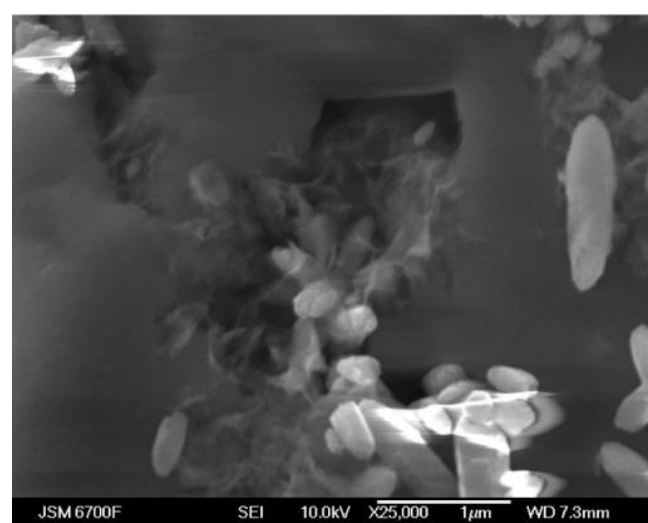

(a)

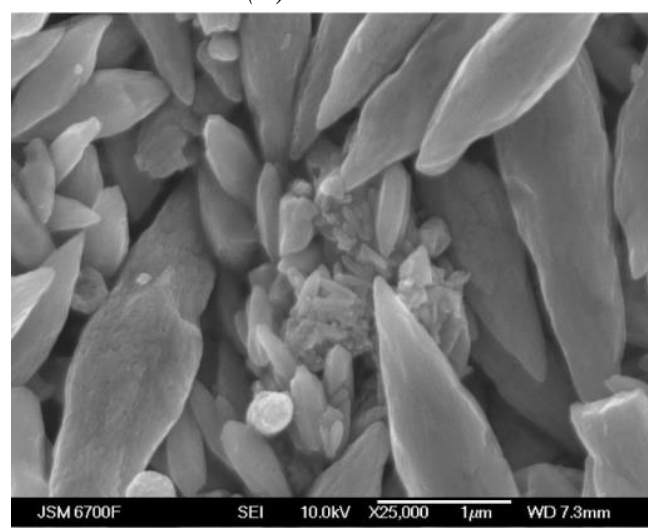

(c)

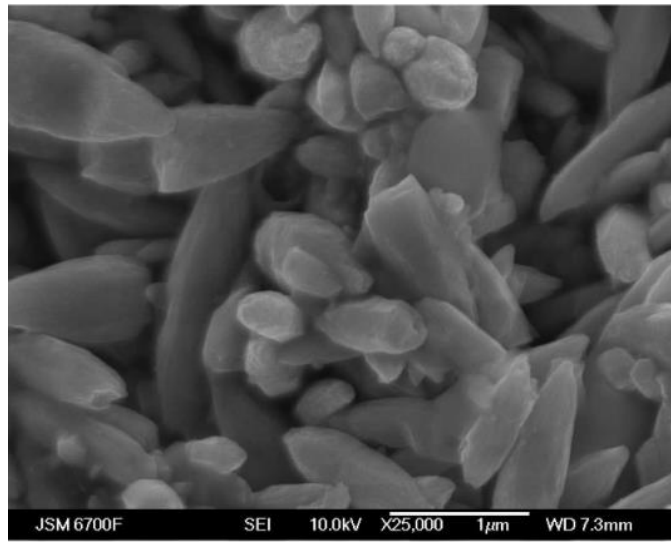

(b)

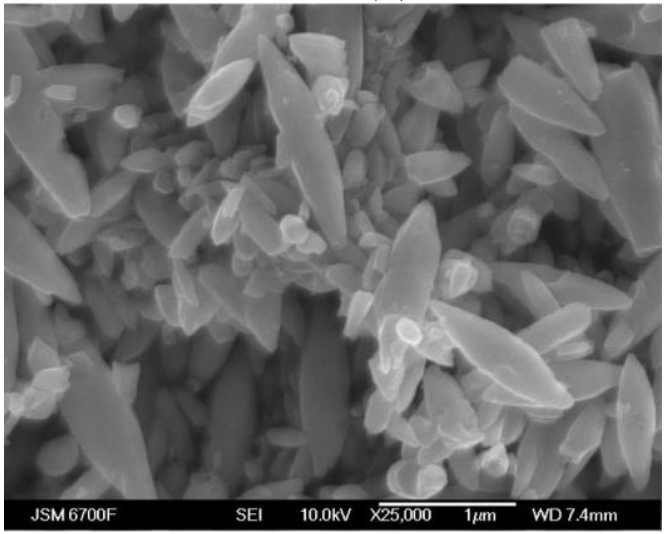

(d)

Fig. 2.ZnO nanoparticles synthesized without stabilizers at the following conditions:(a) $1 \mathrm{~A}$ ( $25 \mathrm{~mA} / \mathrm{cm}^{2}, 5 \mathrm{~min}$ ), (b) $1 \mathrm{~B}\left(50 \mathrm{~mA} / \mathrm{cm}^{2}, 5 \mathrm{~min}\right)$, (c) $1 \mathrm{D}\left(100 \mathrm{~mA} / \mathrm{cm}^{2}, 5 \mathrm{~min}\right),(\mathrm{d}) 1 \mathrm{D}+\left(100 \mathrm{~mA} / \mathrm{cm}^{2}, 15 \mathrm{~min}\right)$.

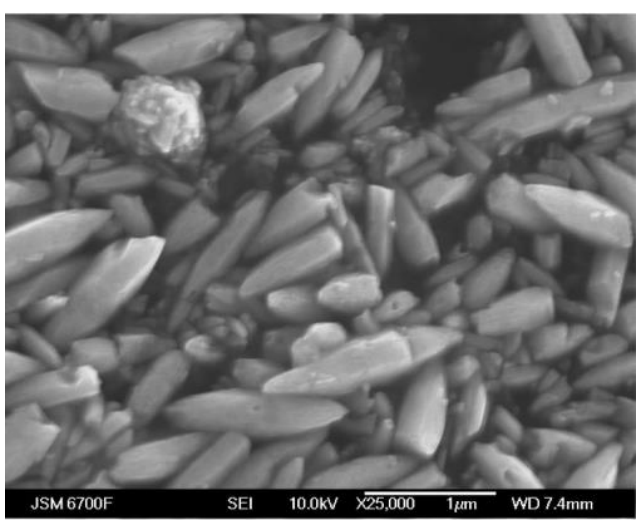

(a)

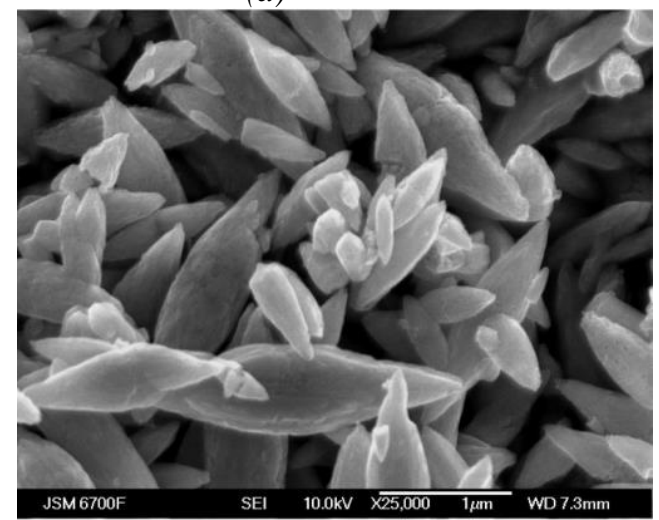

(c)

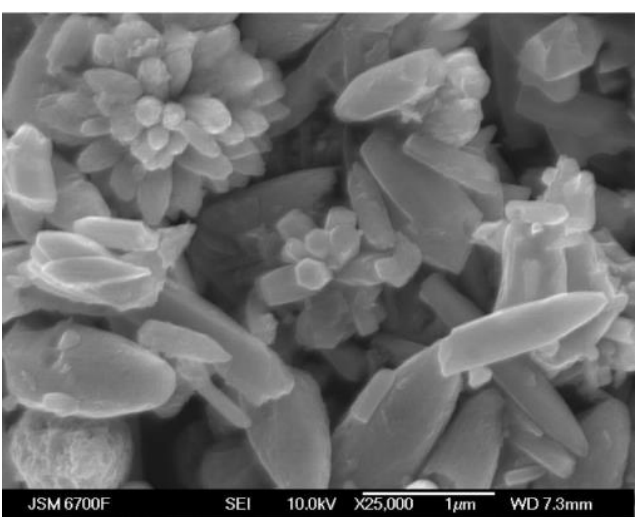

(b)

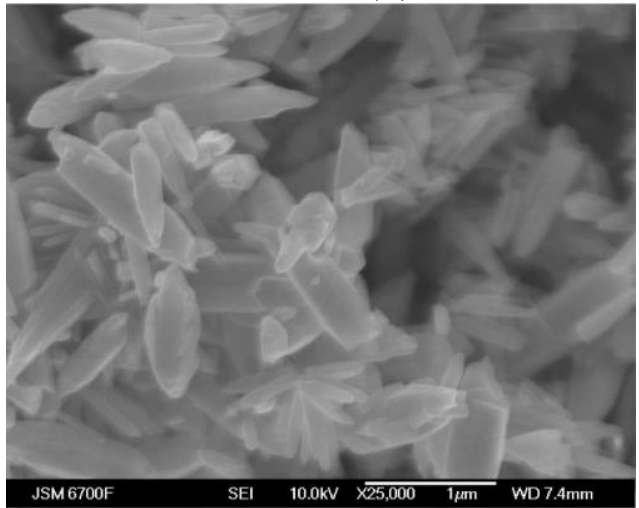

(d)

Fig. 3.Stabilized $\mathrm{ZnO}$ nanoparticles:(a) 2D, (urea, $32 \mathrm{~mA} / \mathrm{cm}^{2}, 5 \mathrm{~min}$ ), (b) $2 \mathrm{D}+$ (urea, $32 \mathrm{~mA} / \mathrm{cm}^{2}, 15 \mathrm{~min}$ ), (c) 3D (PVA, $32 \mathrm{~mA} / \mathrm{cm}^{2}, 5 \mathrm{~min}$ ), (d)3D+ (PVA, $32 \mathrm{~mA} / \mathrm{cm}^{2}, 15 \mathrm{~min}$ ). 


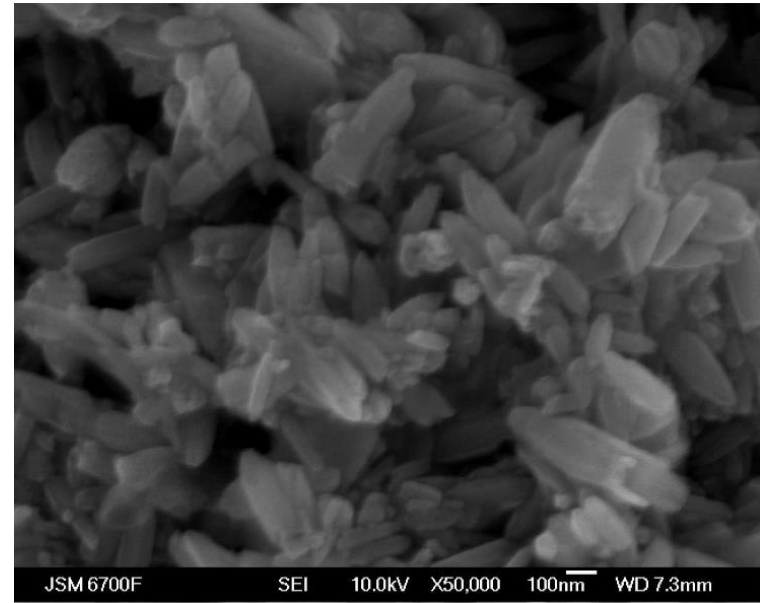

(a)

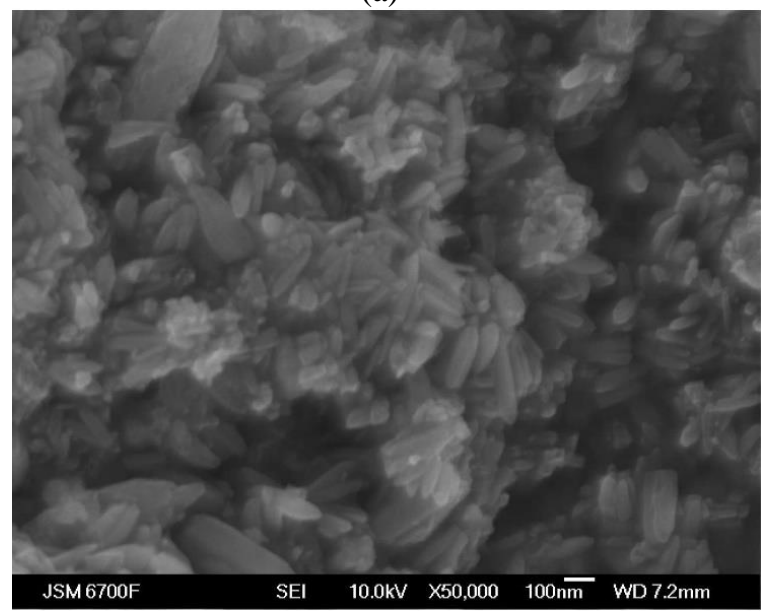

(c)

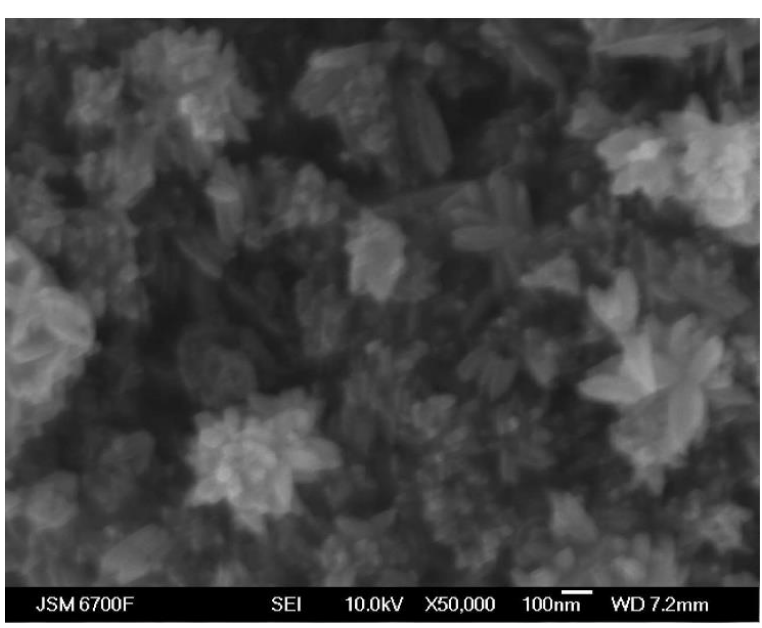

(b)

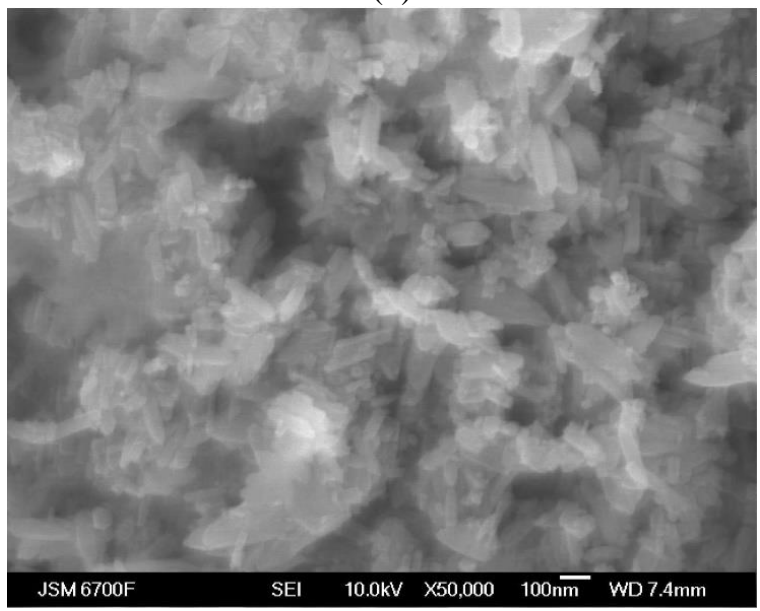

(d)

Fig. 4.ZnO nanoparticles stabilized with atlas:(a) 4A, (25 mA/ $\left.\mathrm{cm}^{2}, 5 \mathrm{~min}\right)$, (b) $4 \mathrm{C}\left(75 \mathrm{~mA} / \mathrm{cm}^{2}, 5 \mathrm{~min}\right)$, (c) $4 \mathrm{D} *\left(100 \mathrm{~mA} / \mathrm{cm}^{2}, 10 \mathrm{~min}\right),(\mathrm{d}) 4 \mathrm{D}+\left(100 \mathrm{~mA} / \mathrm{cm}^{2}, 15 \mathrm{~min}\right)$.

in both short (compare Figures 2(c) and 5(c)) and long (Figures 2(d) and 5(d)) syntheses.

The findings with Atlas G3300 are the most exciting (Fig. 4). It gives consistently small particles independent of the length of the synthesis. In addition to be suitable for both short and long syntheses, it reduces the size of $\mathrm{ZnO}$ particles by about 10 times (compared to the unstabilized syntheses) in all the conditions tested (note that the magnification is 25000 on figures 2 and 5 and 50000 on Figure 4). The use of Atlas G3300 as a stabilizer results in a product with a narrow size distribution. In addition to decreasing the particle size, Atlas G3300 also changes the shape of the product. The particles are now more rod-like, less pointy at the edges.

The effect on particle size and morphology is repeatable as demonstrated by replicating the results of this study.

Earlier we found that flower-like $\mathrm{ZnO}$ aggregates have much higher piezoelectric sensitivity coefficients [38]. There are other studies reporting superior properties of flower-like $\mathrm{ZnO}$ nano-aggregates [11,14-16]. It is therefore worth noting here, that urea and Atlas G3300 facilitated the formation of flower-like aggregates at small current densities (Figures 5(b) and 4(b)). Unfortunately, the optimal conditions to promote the formation of the flower-like structures are not yet clear. The aggregates are, however, sensitive to both current density and electrolysis time.

\section{Experimental}

Materials: $99.9 \%$ rectangular zinc purified by galvanization was and distilled water was used all throughout. $\mathrm{NaCl}$, Atlas $\mathrm{G} 3300$ and urea were obtained from Sigma-Aldrich, $97 \%$ Triton X-100 $(n=6-8)$ was purchased from MERX, and chemically purified grade PVA $(n \approx 200$, MW about $15 \mathrm{kDa})$.

The structural formulas of the stabilizers used are given below:

ZnO nanorod synthesis: $\mathrm{ZnO}$ nanorods were synthesized in a two-electrode $50 \mathrm{~g} / \mathrm{L}(0.856 \mathrm{~mol} / \mathrm{L}) \mathrm{NaCl}-$ aqueous system with pure $(99.9 \%)$ rectangular zink electrodes. The temperature was maintained at $363 \pm 2 \mathrm{~K}$. B5-46 AC/DC converter was used to generate direct current. Solutions (except for control) contained one of the four stabilizers tested with the following concentrations: $10 \mathrm{~g} / \mathrm{L}$ urea, $2 \mathrm{~g} / \mathrm{L}$ PVA, $120 \mathrm{mg} / \mathrm{L}$ (saturated) Triton X100, and $1 \mathrm{~g} / \mathrm{L}$ Atlas G3300. Each stabilizer was tested at five current densities $\left(25,50,75,100\right.$ and $\left.125 \mathrm{~mA} / \mathrm{cm}^{2}\right)$ and up to three electrolysis times $(5,10$ and 15 minute) giving a total of 31 sets of conditions (see Table 1). 
<smiles>NC(N)=O</smiles>

(a)<smiles>CCC(O)CC(C)(C)C</smiles>

(b)<smiles>CCCCCCCCCC(CC)c1ccc(S(=O)(=O)[O-])cc1</smiles>

(d)

Fig. 5. Stabilizers, tested in this study. (a) urea, (b) polyvinyl alcohol, (c) Triton X-100 or 2-(4-(2,4,4-trimethylpentan-2-yl)phenoxy)oligoepoxy-ethan-1-ol, (d) Atlas G3300 or 4-dodecan-3-ylbenzenesulfonic acid;propan-2-amine.

Synthesized $\mathrm{ZnO}$ was decanted, washed with distilled water and dried in the oven at $50{ }^{\circ} \mathrm{C}$ overnight. Some experiments were repeated to test for the reproducibility. The differences in particle size distributions of replicate samples were not statistically significant.

Particle characterization: Powder X-ray diffraction was carried out using DRON 4-13(Cu $K_{\alpha}, S i$ as ethalon, $41 \mathrm{kV}, 21 \mathrm{~mA})$ on the range $2 \Theta$ of 10 to $75^{\circ}$. Obtained spectra were compared to $\mathrm{ZnO}, \mathrm{Zn}(\mathrm{OH})_{2}, \mathrm{Zn}$ in CSD.

SEM of $\mathrm{ZnO}$ was performed using the field emission scanning electron microscope (SEM) JSM-6700F produced by JEOL Ltd. (Japan). Morphology of the powders was investigated in secondary electron imaging (SEI) mode at 100-200 pA beam current and $10 \mathrm{kV}$ accelerating voltage. The vacuum level inside the SEM specimen chamber was at least $9.3 \times 10^{-5} \mathrm{~Pa}$.

\section{Conclusion}

Addition of size stabilizers improves the synthetic prospective of a 2-electrode electrodeposition of $\mathrm{ZnO}$ significantly. In addition to the simplicity, high yields and low cost, inherent in the method, it also acquires a way to control the shape and size of $\mathrm{ZnO}$ particles synthesized electrochemically. In particular, Atlas G3300 should be the stabilizer of choice to make uniformly sized 100 to 200-nm long $\mathrm{ZnO}$ nanorods (depending on current density).

\section{Acknowledgements}

Authors thank Minor Academy of Sciences of Ukraine for provided funding. Special thanks to Dr. Halyna Yagenska and Mrs. Nadia Bobak for their continuous support.

R.V. Korol - Honors BSc., Graduate student; O.M. Yanchuk - Candidate of Chemical Sciences (PhD), Associate Professor;

O.V. Marchuk - Candidate of Chemical Sciences (PhD), Associate Professor

V.F. Orlov - Doctor of Pedagogy, Senior research fellow, Full Professor;

I.A. Moroz - Candidate of Chemical Sciences (PhD), Associate Professor;

O.A. Vyshnevskyi - Candidate of Geological Sciences (PhD), Leading Researcher.

[1] G.-C. Yi, C. Wang, and W.I. Park, Semiconductor Science and Technology 20, S22 (2005); https://doi.org/10.1088/0268-1242/20/4/003.

[2] Z.L. Wang, Chinese Science Bulletin 54, 4021 (2009); https://doi.org/10.1007/s11434-009-0456-0.

[3] A. Moulahi, and F. Sediri, Optik - International Journal for Light and Electron Optics 127, 7586 (2016); https://doi.org/10.1016/j.ijleo.2016.05.128.

[4] Ü. Özgür,Y.I. Alivov, C. Liu,A. Teke, M.A. Reshchikov, S. Doğan, V. Avrutin,S.-J. Cho, and H. Morkoç, Journal of Applied Physics 98, 41301 (2005); https://doi.org/10.1063/1.1992666.

[5] S. Chu, G. Wang, W. Zhou, Y. Lin, L. Chernyak, J. Zhao, J. Kong, L. Li, J. Ren, and J. Liu, Nature Nanotechnology 6, 506 (2011); https://doi.org/10.1038/nnano.2011.97.

[6] J.H. Na, M. Kitamura, M. Arita, and Y. Arakawa, Applied Physics Letters 95, 253303 (2009); https://doi.org/10.1063/1.3275802. 
[7] Z. Huang, Y. Dou, K. Wan, F. Wu, L. Fang, H. Ruan, B. Hu, F. Meng, and M. Liao, Journal of Materials Science: Materials in Electronics (2017); https://doi.org/10.1007/s10854-017-7675-y.

[8] S.M. Saleh, A.M. Soliman, M.A. Sharaf, V. Kale, and B. Gadgil, Journal of Environmental Chemical Engineering 5, 1219 (2017); https://doi.org/http://dx.doi.org/10.1016/j.jece.2017.02.004.

[9] Z.L. Wang, R. Yang, J. Zhou, Y. Qin, C. Xu, Y. Hu, and S. Xu, Materials Science and Engineering: R: Reports 70, 320 (2010); https://doi.org/http://dx.doi.org/10.1016/j.mser.2010.06.015.

[10] B. Renganathan, and A.R. Ganesan, Optical Fiber Technology 20, 48 (2014); https://doi.org/10.1016/j.yofte.2013.11.007.

[11] L. Zhu,Y. Li, and W. Zeng, Physica E: Low-dimensional Systems and Nanostructures 94, 123 (2017); https://doi.org/http://dx.doi.org/10.1016/j.physe.2017.08.004.

[12] A.F. Abdulrahman, S.M. Ahmed,N.M. Ahmed, and M.A. Almessiere, AIP Conference Proceedings 1875, 20004 (2017); https://doi.org/10.1063/1.4998358.

[13] C.B. Ong, L.Y. Ng, and A.W. Mohammad, Renewable and Sustainable Energy Reviews 81, 536 (2018); https://doi.org/10.1016/j.rser.2017.08.020.

[14] S. Ameen, M.S. Akhtar, and H.S. Shin, Materials Letters (2017); https://doi.org/10.1016/j.matlet.2017.07.117.

[15] M. Cao, F. Wang, J. Zhu, X. Zhang,Y. Qin, and L. Wang, Materials Letters 192, 1 (2017); https://doi.org/10.1016/j.matlet.2017.01.051.

[16] X. Lv, X. Liu, Q. Sun, Y. Wang, and B. Yan, Ceramics International 43, 3306 (2017); https://doi.org/http://dx.doi.org/10.1016/j.ceramint.2016.11.168.

[17] T. Giunta, E.D. Young, O. Warr, I. Kohl, J.L. Ash, A. Martini, S.O.C. Mundle, D. Rumble, I. Pérez-Rodríguez, M. Wasley, D.E. LaRowe, A. Gilbert, and Sherwood Lollar, B. Geochimica et Cosmochimica Acta, Elsevier Ltd, 245, 327 (2019); https://doi.org/10.1016/j.gca.2018.10.030.

[18] N. Izyumskaya, A. Tahira, Z.H. Ibupoto, N. Lewinski, V. Avrutin, Ü. Özgür, E. Topsakal, M. Willander, and H. Morkoç, ECS Journal of Solid State Science and Technology 6, Q84 (2017); https://doi.org/10.1149/2.0291708jss.

[19] J. Zhou, N.S. Xu, and Z.L. Wang, Advanced Materials 18, 2432 (2006); https://doi.org/10.1002/adma.200600200.

[20] N.S. AlZayed, JeanEbothé, J. Michel, I.V. Kityk, O.M. Yanchuk, D.I. Prots, and O.V. Marchuk, Physica E 60, 220 (2014); https://doi.org/10.1016/j.physe.2014.01.032.

[21] Z.R. Tian, J.A. Voigt, J. Liu, B. Mckenzie, M.J. Mcdermott, M.A. Rodriguez, H. Konishi, and H. Xu, Nature Materials 2, 821 (2003); https://doi.org/10.1038/nmat1014.

[22] Z. Zarghami,M. Ramezani, and K. Motevalli, Journal of Cluster Science 27, 1451 (2016); https://doi.org/10.1007/s10876-016-1011-1.

[23] C. Li, G. Fang, J. Li, L. Ai, B. Dong, and X. Zhao, The Journal of Physical Chemistry C 112, 990 (2008); https://doi.org/10.1021/jp077133s.

[24] C. GZ, The Journal of Physical Chemistry B 108, 19921 (2004); https://doi.org/10.1021/jp040492s.

[25] Y. Zhou, L. Xu, Z. Wu, P. Li, and J. He, Optik - International Journal for Light and Electron Optics 130, 673 (2017); https://doi.org/10.1016/j.ijleo.2016.10.119.

[26] S. Sönmezoğlu, V. Eskizeybek, A. Toumiat, and A. Avc1, Journal of Alloys and Compounds 586, 593 (2014); https://doi.org/http://dx.doi.org/10.1016/j.jallcom.2013.10.102.

[27] D. Yolaçan, and N.D. Sankir, Journal of Alloys and Compounds (2017); https://doi.org/http://dx.doi.org/10.1016/j.jallcom.2017.07.314.

[28] W. Feng, P. Huang, B. Wang, C. Wang, W. Wang, T. Wang, S. Chen, R. Lv, Y. Qin, and J. Ma, Ceramics International 42, 2250 (2016); https://doi.org/http://dx.doi.org/10.1016/j.ceramint.2015.10.018.

[29] J.-H. Kim, K.-W. Kim, K.-S. Ryu, and K.-K. Cho, Materials Technology 27, 18 (2012); https://doi.org/10.1179/175355511X13240279339527.

[30] D. Pradhan, S. Sindhwani, and K.T. Leung, Nanoscale Research Letters 5, 1727 (2010); https://doi.org/10.1007/s11671-010-9702-2.

[31] X.-J. Wu, F. Zhu, C. Mu, Y. Liang, L. Xu, Q. Chen, R. Chen, and D. Xu, Coordination Chemistry Reviews 254, 1135 (2010); https://doi.org/http://dx.doi.org/10.1016/j.ccr.2010.02.014.

[32] L. Zaraska, K. Mika, K. Syrek, and G.D. Sulka, Journal of Electroanalytical Chemistry 801, 511 (2017); https://doi.org/http://dx.doi.org/10.1016/j.jelechem.2017.08.035.

[33] Y.-C. Wang, I.-C. Leu, and H. Min-Hsiung, Electrochemical and Solid-State Letters 5, C53 (2002); https://doi.org/10.1149/1.1454547.

[34] Y.C. Wang, I.C. Leu, and M.H. Hon, J. Mater. Chem., The Royal Society of Chemistry 12, 2439 (2002); https://doi.org/10.1039/B111189M.

[35] S. Peulon, and D. Lincot, Advanced Materials, WILEY-VCH Verlag GmbH 8, 166 (1996); https://doi.org/10.1002/adma.19960080216.

[36] G. Jiangfeng, D. Zhaoming, D. Qingping, X. Yuan, and Z. Weihua, Journal of Nanomaterials (2010); https://doi.org/10.1155/2010/740628.

[37] O.M. Yanchuk, J. Ebothé, A.M. El-Naggar, A. Albassam, L.V. Tsurkova, O.V. Marchuk, G. Lakshminarayana, S. Tkaczyk, I.V. Kityk, A.O. Fedorchuk, O.M. Vykhryst, and I.V. Urubkov, Physica E 86, 184 (2017); https://doi.org/10.1016/j.physe.2016.10.028. 
[38] A.H. Reshak, O.M. Yanchuk, D.I. Prots, L.V. Tsurkova, O.V. Marchuk, I.V. Urubkov, V.A. Pekhnyo, O. Fedorchuk, Z.A. Alahmed, and H. Kamarudin, Int. J. Electrochem. Sci. 9, 6378 (2014).

[39] J. Yang, G. Liu, J. Lu, Y. Qiu, and S. Yang, Applied Physics Letters 90, 103109 (2007); https://doi.org/10.1063/1.2711532.

[40] C.H. Voon, B.Y. Lim, K.L. Foo, L.N. Hashim, S.A. Ho, and S.A. Ong, Nanoscience \& Nanotechnology-Asia 7 (2017); https://doi.org/10.2174/2210681207666170615114602.

[41] L. Ding, R. Zhang, and L. Fan, Nanoscale Research Letters 8, 78 (2013); https://doi.org/10.1186/1556-276X-878.

[42] N. Lepot, M.K. Bael, Van, H. Van den Rul, J. D’Haen, R. Peeters, D. Franco, and Mullens, J. Materials Letters 61, 2624 (2007); https://doi.org/10.1016/j.matlet.2006.10.025.

[43] S. Kumar, H.-J., Lee, T.-H. Yoon, C.N. Murthy, and J.-S. Lee, Crystal Growth I\& Design, 16, 3905 (2016); https://doi.org/10.1021/acs.cgd.6b00479.

[44] Z. Li, Y. Xiong, and Y. Xie, Inorganic Chemistry 42, 8105 (2003); https://doi.org/10.1021/ic034029q.

[45] S. Duo, Y. Li, H. Zhang, T. Liu, K. Wu, and Z. Li, Materials Characterization 114, 185 (2016); https://doi.org/http://dx.doi.org/10.1016/j.matchar.2016.02.021.

[46] Y. Guo, S. Lin, X. Li, and Y. Liu, Applied Surface Science 384, 83 (2016); https://doi.org/10.1016/j.apsusc.2016.04.036.

[47] S. Duo, Y. Li, Z. Liu, R. Zhong, and T. Liu, Materials Science in Semiconductor Processing 56, 196 (2016); https://doi.org/http://dx.doi.org/10.1016/j.mssp.2016.08.018.

[48] N.A. Ibrahim, A.A. Nada, A.G. Hassabo, B.M. Eid, A.M. Noor El-Deen, and N.Y. Abou-Zeid, Chemical Papers 71, 1365 (2017); https://doi.org/10.1007/s11696-017-0132-9.

[49] T. Marimuthu, and N. Anandhan, AIP Conference Proceedings 1832, 80014 (2017); https://doi.org/10.1063/1.4980474.

[50] E. Kouhestanian, S.A. Mozaffari, M. Ranjbar, H. SalarAmoli, and M.H. Armanmehr, Superlattices and Microstructures 96, 82 (2016); https://doi.org/http://dx.doi.org/10.1016/j.spmi.2016.05.012.

[51] R. Rameshbabu, N. Kumar, A. Karthigeyan, and B. Neppolian, Materials Chemistry and Physics 181,106 (2016); https://doi.org/http://dx.doi.org/10.1016/j.matchemphys.2016.06.040.

[52] R.A. Picca, M.C. Sportelli, R. Lopetuso, and N. Cioffi, Journal of Sol-Gel Science and Technology 81, 338 (2017); https://doi.org/10.1007/s10971-016-4268-9.

[53] D.O. Miles, P.J. Cameron, and D.J. Mattia, Mater. Chem. A, The Royal Society of Chemistry 3, 17569 (2015); https://doi.org/10.1039/C5TA03578C.

\title{
Р.В. Король ${ }^{1}$, О.М. Янчук², О.В. Марчук ${ }^{2}$, В.Ф. Орлов ${ }^{3}$, I.А. Мороз ${ }^{4}$, О.А. Вишневський ${ }^{5}$ \\ Двохелектродний синтез наночастинок ZnO в присутності різних стабілізаторів
}

\author{
${ }^{1}$ Технічний інститут Каліфорнії, Пасадена, США, rkorol@ caltech.edu \\ ${ }^{2}$ Волинський національний університет імені Лесі Украӥнки, Луиьк, Україна, yanchuk59@ gmail.com \\ ${ }^{3}$ Iнститут професійно-технічної освіти НАПН Украӥни, Київ, Україна, v.f.orlov@ukr.net \\ ${ }^{4}$ Луцький національний технічний університет, м. Луцьк, Украӥна, moroz.irynal@gтаil.com \\ 5Інститут геохімії, мінералогї̈ та рудоутворення імені М.П. Семененка НАН України, Київ, Україна, vуshnеvskyу@i.иа
}

\begin{abstract}
Модифіковано та оптимізовано дешевий, простий та ефективний синтез нанорозмірних частинок цинк оксиду шляхом електроосадження. Метод полягає у синтезі $\mathrm{ZnO}$ в електродній чарунці з двома цинковими електродами та водним розчином натрій хлориду. Утворені частинки мають пластинчасту форму: розширені посередині і звужені по краях. Частинки мають однакову форму, але широкий розподіл за розміром з більшістю частинок $\mathrm{ZnO}$ довжиною 1 - 2 мкм і товщиною 0,5 - 0,7 мкм. Стабілізатори додають у водну фазу, щоб зменшити розмір і звузити його розподіл у цільовому продукті. В цій роботі ми представляємо стабілізуючу дію чотирьох таких стабілізаторів: сечовини, полівінілового спирту, Тритону X-100 та атласу. Усі вони зменшують розмір частинок і полідисперсність. Аніонний поверхнево-активний Атлас G3300 є найефективнішим, і забезпечує зменшення розміру наночастинок на порядок.

Ключові слова: $\mathrm{ZnO}$, наночастинки, електроосадження, окислення, ПАР.
\end{abstract}

